\title{
EPIDURAL ANAESTHESIA IN INFANTS AND CHILDREN*
}

\author{
F. G. Ruston, M.D.*
}

Twrs is a report on the use of epidural anaesthesia in infants and children in the hospitals of Hamilton, Ontario, to the present date. Preliminary papers have been given at a Clinical Day programme in 1950 and again at a Sectional meeting of the Ontario Medical Association in May, 1952. I shall of course include material from those reports, although our technique has been modified since its first use in 1949.

After careful search of the literature, I have found only one reference to the use of this form of conduction anaesthesia in paediatric surgery. It is "Peridural Anaesthesia for Cystoscopy in the Child" by Roderic Sievers (1). In this paper the author also reports 21 cases in which "other operations were performed (four on the kidneys, six on the peripheral urinary paths, eight radical operations for hernia, and three appendectomies)." He used 1 per cent novocaine-suprarenin solution in amazing doses $-15 \mathrm{cc}$. for a $5 \mathrm{~kg}$. infant with an increase of $5 \mathrm{cc}$. for each $5 \mathrm{~kg}$. to a maximum of $50 \mathrm{cc}$. for a 35 to $50 \mathrm{~kg}$. person.

My interest in epidural anaesthesia, was aroused while I was overseas with a Canadian Hospital, after reading Dogliotti's description of this segmental anaesthetic technique (2). I used this technique as often as I could, where it was feasible, especially for the poor risk group. As a result, when I was booked for a moribund infant with pyloric stenosis in 1949, I felt that epidural anaesthesia might be the answer. The result was so gratifying that I was encouraged to make further use of it for pylorics. Now several members of our staff are using this block anaesthetic. The number of anaesthetics is small, but enough have been given to see the application.

\section{Anatomical Considerations}

The epidural, peridural or extradural space is that portion of the vertebral canal which is not occupied by the dura mater and its contents. It separates the dura from the ligaments and the periostium which are the walls of the vertebral canal. Above, this space ends at the foramen magnum where the dura splits into two layers, one of which forms the endostium of the skull. Below, it is continuous with the sacral canal, terminating at the membrane across the caudal hiatus. Laterally, it communicates with the paravertebral tissues through the many intervertebral foramina and surrounds the dural sleeves which follow the nerves for varying distances. The epidural space contains loose areolar tissue, vascular plexuses, and fibrous extensions from the dura to the longitudinal ligaments. Usually there is a negative pressure which becomes more marked when the spine is flexed.

Method

I intend to discuss the thoraco-lumbar approach to the space. However, one

'Presented at a meeting of the Ontario Division, Canadian Anaesthetists' Society, Ottawa, April 3, 1954.

*Hamilton, Ontario. 
must remember that there is also a caudal approach. In fact, one patient with severe imperforate anus was successfully anaesthetized by the caudal method. Originally procaine 1 or 2 per cent was used as the agent in these cases. However, since the introduction of xylocaine, we have used it to the exclusion of procaine, and only in the single dose method. The actual technique for epidural tap has been described by Dogliotti (2) and others, but when this is applied to infants, a difficulty arises from the diminutive structures and from the finer texture of tissues which are traversed by the needle point.

The following is the sterile kit we use for infants and children (Figure 1).

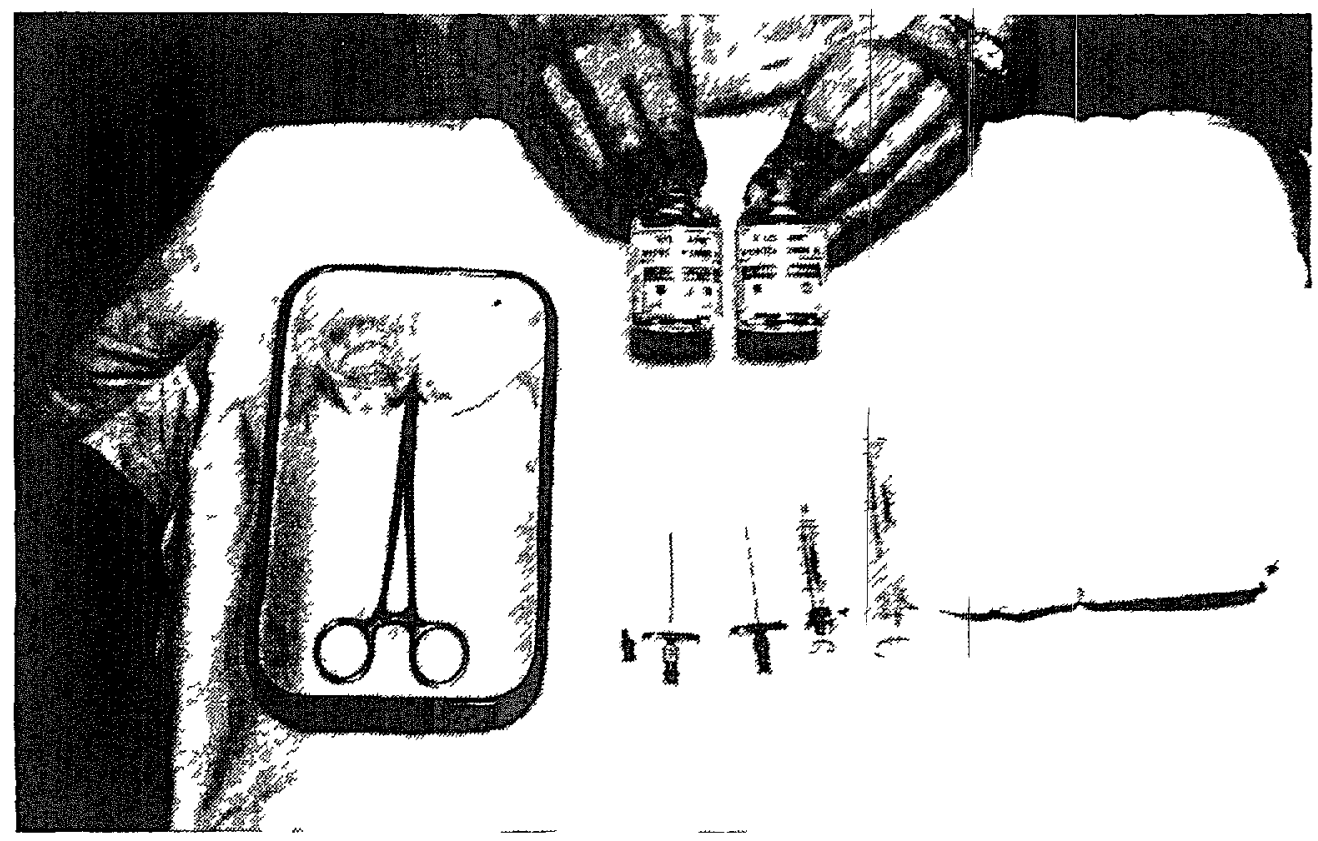

Figure 1 The kit used for epidural anaesthesia in infants

There are two syringes, one $10 \mathrm{cc}$. and the other a $2 \mathrm{cc}$, two epidural needles and a hypodermic needle. Of course, there is a spinal sheet and a preparation tray. Xylocaine 1 per cent with and without epinephrine $1 / 100,000$ is contained in rubber-stoppered vials. Since it is believed that $1 / 200,000$ epinephrine is the safest solution to use ( 3 ), it is mixed in equal parts in the syringe. Xylocaine 2 per cent solution has been used for prolonged operations in the past, but I believe that a 1 per cent solution is adequate in most cases. Originally, a No. 20 short bevelled intravenous needle was used for the tap, but this was discontınued when the needle was found to be plugged after insertion into the interspinous ligament in two cases. Now we use a two-inch No. 22 gauge short bevelled spinal needle with added flanges and stillette. For children a No. 20 gauge is used. The hypodermic needle is for the skin wheal, and to place the hanging drop which will be described later.

In regard to preanaesthetic sedation, I believe that the schedule followed by Leigh and Belton (4) is adequate. We do not use morphine in infants and small children as there is a definite added risk in a training school hospital. Codeine in equivalent dosage is preferred. Also, a cut down should be done preoperatively 
where indicated, although over half the pyloric stenosis cases in this senies were treated without intravenous infusion. Furthermore, subcutaneous injections should not be started on the dorsal area, as this gives risel to oedema and makes the tap more difficult and hazardous.

The position in which the infant is held for the tap is very important. At first, the lateral position was used, but it was found that the infant frequently squirmed, making a fluidless tap more difficult. Finally, the sitting position was found to be the choice, for when the infant is clasped by the assistant with knees and elbows together little movement is possible. When this is done properly, the spine is nicely flexed and the spinal interspaces are readily palpable (Figure 2). Care must be taken not to obstruct breathing, especially in the presence of

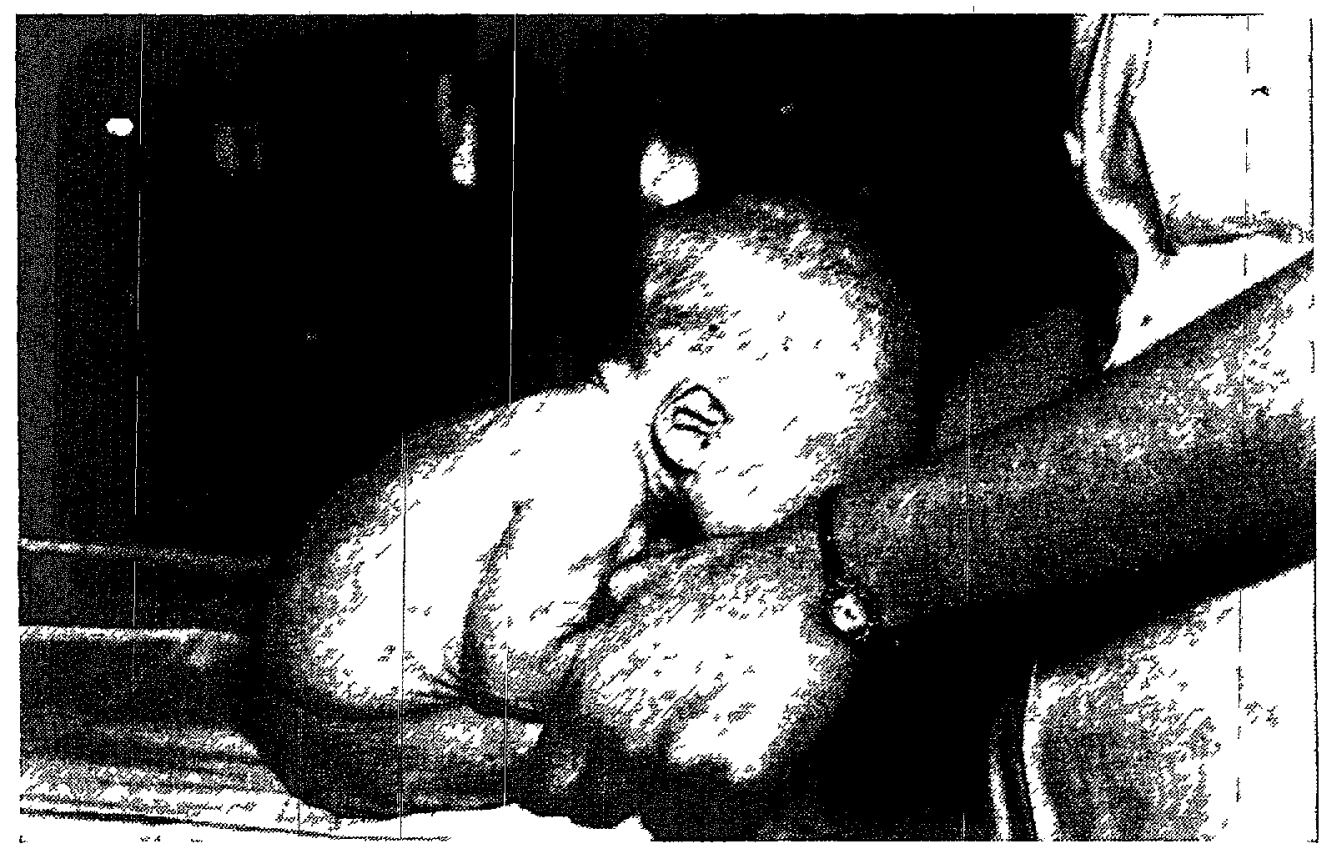

Figure 2 The position of the child The infant is clasped by the assistant with the elbows and knees together.

abdominal distention. The skun of the back is prepared and draped and the needle is placed with or without a skm wheal in a suitable interspace-usually between T10 and L1 for upper abdominal procedures, and L2 to L4 for a hernia or orthopaedic procedure involving the hip area. The needle is advanced well into the interspinous ligament, generally about $\%$ inch, and the stilette is removed. A drop of anaesthetic solution is placed, over the hub of the needle with the hypodermic needle and syringe. Then the epidural needle is cautiously advanced and the action of tre hanging drop is watched under a good light (Figure 3). One must be aware of the lessening of tissue resistance as the epidural space is entered. The hanging drop at this time is sucked into the needle. Rarely does one do a spinal tap if the drop is closely observed. In such an event the needle may be reinserted in another interspace. The desired amount of anaesthetic solution is then injected, the average infant receiving 5 to $6 \mathrm{cc}$. I used to inject $1 \mathrm{cc}$. and wait for five minutes to see if a spinal anaesthetic developed, but now I inject the 


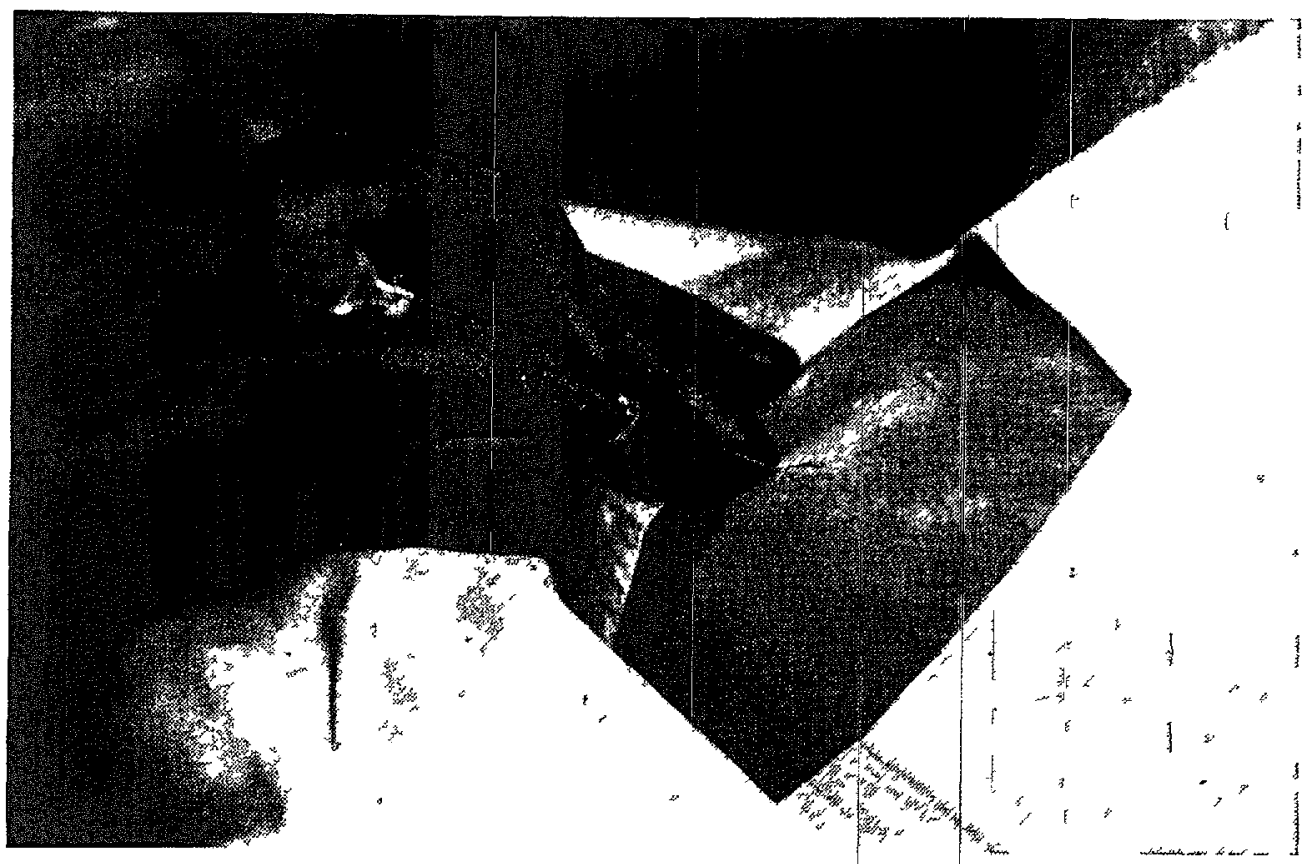

Figure 3. The "Hanging drop" in the needle hub is illustrated. This drop is sucked into the hub when the needle enters the epidural space

full amount slowly but continuously because I believe that there is very little chance of piercing the dura when it is pushed away from the blunt needle point by the volume of anaesthetic fluid. Moreover, if the injection is prolonged, the chance of the infant's straining and forcing the dura against the needle is apparent. The needle is withdrawn and the puncture site sponged vigorously, as frequently one notices a slight leak of anaesthetic solution from the needle path. The infant is immediately placed in a supine position and restrained to a padded board by flannel bandages. Within a few minutes, there is definite evidence of decreased abdominal tone (Figure 4). Preparation and operation can be started within 5 or 10 minutes following the injection of the anaesthetic. If the infant is restless, a minute amount of pentothal may be given intravenously, or by catheter into the stomach, if a catheter has been passed to see if the stomach is empty. Nitrous oxide or light cyclopropane can also be given with a loosely placed infant's mask. Oxygen can also be given in this manner. Quite often the infant is content to suck the anaesthetist's finger-better still, an old-fashioned pacifier.

\section{Clinical Cases}

The following table shows briefly what we have done with epidural anaesthesia, alone and combined. The cases listed are those which I have done personally. Since this was written, I have used it for two more pylorics. Thirty-one additional pylorics and one duodenal atresia have been completed by other members of our staff, which brings the total to 77 cases.

Supplements were given to ensure there was no stirring of the shoulders or crying. Pentothal generally was for sedation effect. As you see, cyclopropane 


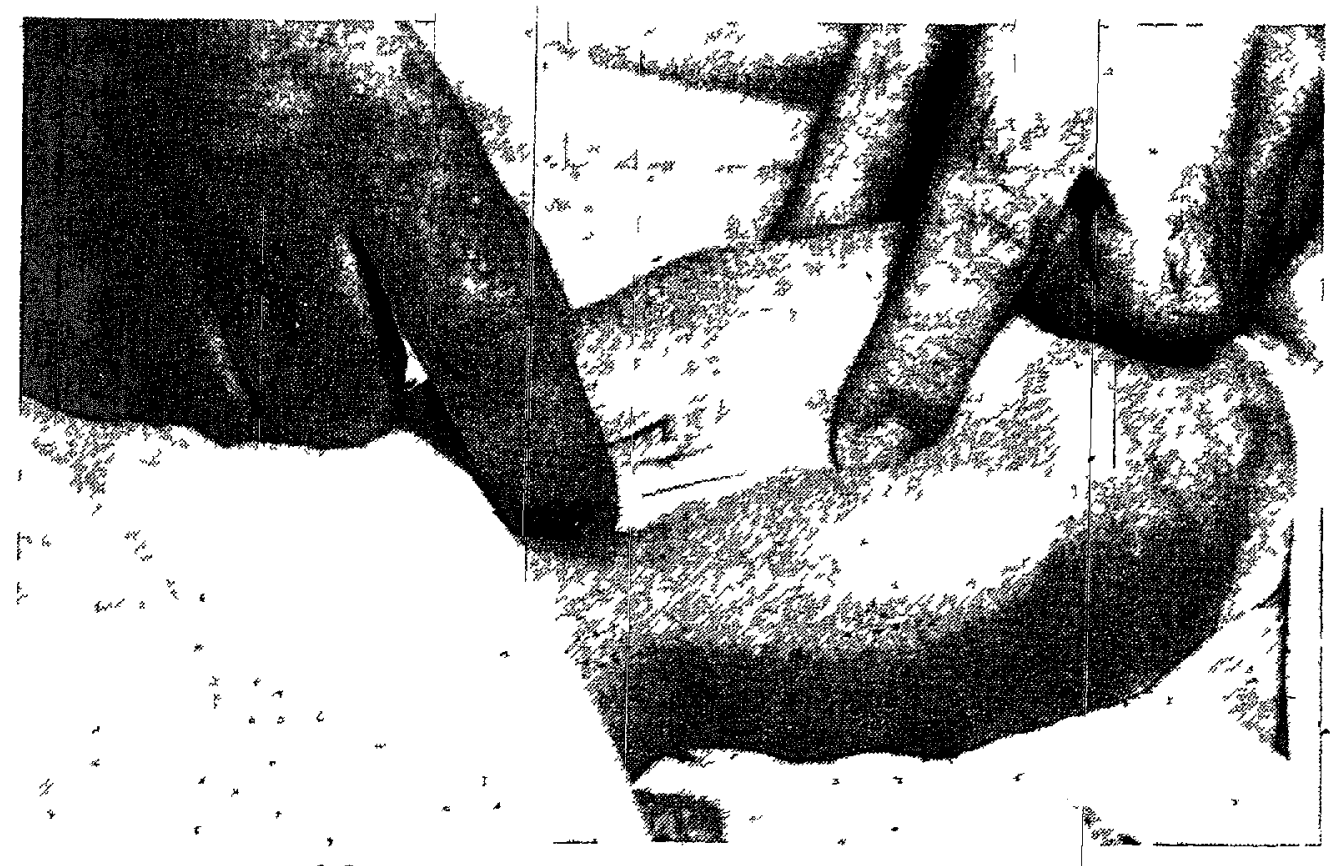

Figure 4. The abdominal wall is well relaxed and the pyloric tumour is evident.

was given only in cases where the segmental anaesthesia was inadequate. The complications could be attributed to the anaesthetic in only one case, and that was when there was a subcutaneous reaction to old blood which had plugged a needle. One patient was over-sedated, i e., did not metabolize the sedative for twelve hours due to a ketosis and a middle ear infection. Two cases of convulsions could not be blamed on the xylocaine, for one followed definite over-loading of an infant with pyloric stenosis with transfusion and intravenous glucose and saline. The other convulsion developed with the breakdown of a gangrenous intussusception. In this case the convulsions were controlled by 4 cc. pentothal into the stomach and a twenty-minute apnoea developed in 5 minutes, showing how quickly the stomach will absorb pentothal. The infant with the volvulus was convulsing intermittently before operation and was moribund. The convulsions were controlled with intravenous pentothal and later with sodium luminal in the post-operative period. The only fatality was in the premature infant with jejunal atresia. This infant died three weeks after the last operation from further obstruction.

\section{Discussion}

It can be seen from the reference quoted above that epidural anaesthesia in infants and children is not a new thing. Perhaps it has been neglected in view of our present-day local anaesthetic drugs. Many hospitals | do not have gas machines adaptable for use with infants and small children without a dangerous resistance to breathing and resultant build-up of $\mathrm{CO}_{2}$. Certainly open ether in such cases is not without danger. Offen the added risk of intubation is not justifiable. Some cases with associated respiratory infection or ketosis should have some form of conduction anaesthesia. I believe that epidural block, being a segmental anaesthesia, is more controllable in the infant than a spinal anaes- 
TABLE I

Use of EPIDURal ANaEsThesia

\begin{tabular}{|c|c|c|c|c|}
\hline Operation & Age & Weight & Anaesthetic & Supplement \\
\hline $\begin{array}{l}\text { Pyloroplasty } \\
20 \text { cases }\end{array}$ & $\begin{array}{l}4 \text { to } \\
4 \text { weeks }\end{array}$ & $\begin{array}{l}6 \text { lbs. to } \\
8 \text { lbs. } 15 \mathrm{oz} .\end{array}$ & $\begin{array}{c}8 \text { Procaine } 2 \% \\
3-5 \frac{1}{2} \mathrm{cc} . \\
12 \text { Xylocaine } 1 \% \\
4 \frac{1}{2}-6 \mathrm{cc} .\end{array}$ & $\begin{cases}2 & \mathrm{~N}_{2} \mathrm{O} \\
1 & \text { Cyclo } \\
1 & \text { Pentothal } \\
2 & \text { Pentothal } \\
1 & \text { Cyclo }\end{cases}$ \\
\hline $\begin{array}{l}\text { Hernia repair } \\
2 \text { indirect } \\
2 \text { strangulated } \\
1 \text { bilateral } \\
1 \text { umbilical }\end{array}$ & $\begin{array}{c}2 \text { weeks } \\
\text { to } \\
3 \text { years }\end{array}$ & $8 \mathrm{lbs}$. & $\begin{array}{c}5 \text { Xylocaine } 1 \% \\
5-8 \mathrm{cc} . \\
1 \mathrm{X} \text { ylocaine } 2 \% \\
7 \mathrm{cc} .\end{array}$ & $\begin{array}{l}3 \mathrm{~N}_{2} \mathrm{O} \\
2 \text { Pentothal }\end{array}$ \\
\hline $\begin{array}{l}\text { Intussusception } \\
2 \text { with resections } \\
2 \text { without resections }\end{array}$ & $\begin{array}{l}3 \text { months } \\
\text { to } \\
9 \text { months }\end{array}$ & & $\begin{array}{c}\text { Xylocaine } 2 \% \\
6-8 \text { cc. }\end{array}$ & 2 Pentothal \\
\hline $\begin{array}{l}\text { Volvulus } \\
\text { Bowel resection }\end{array}$ & 6 months & & $\begin{array}{l}\mathrm{X} \text { ylocaine } 2 \% \\
8 \mathrm{cc} .\end{array}$ & Pentothal \\
\hline $\begin{array}{l}\text { Appendectomy } \\
2 \text { gen. peritonitis }\end{array}$ & $\begin{array}{l}3 \text { and } \\
4 \text { years }\end{array}$ & & $\begin{array}{l}\text { Xylocaine } 1 \& 2 \% \\
8 \& 10 \mathrm{cc} .\end{array}$ & 2 Pentothal \\
\hline $\begin{array}{l}\text { Splenectomy } \\
2 \text { for purpura }\end{array}$ & $\begin{array}{l}3 \text { and } \\
7 \text { years }\end{array}$ & & $\begin{array}{l}\text { Xylocaine } 1 \% \\
7 \& 12 \mathrm{cc}\end{array}$ & 2 Pentothal \\
\hline $\begin{array}{l}\text { Laparotomy } \\
\text { Large ovarian dermoid }\end{array}$ & 20 months & & $\begin{array}{l}\text { Xylocaine } 2 \% \\
8 \text { cc. }\end{array}$ & Pentothal \\
\hline $\begin{array}{l}\text { Biopsy of liver } \\
\text { malignancy }\end{array}$ & $6 \frac{1}{2}$ months & & $\begin{array}{l}\text { Xylocaine } 2 \% \\
7 \text { cc. }\end{array}$ & \\
\hline $\begin{array}{r}\text { Jejunal atresia } \\
2 \text { operations }\end{array}$ & $\begin{array}{l}\text { Premature } \\
24 \text { hours }\end{array}$ & 4 lbs. 7 oz. & $\begin{array}{l}\text { Xylocaine } 2 \% \\
3 \frac{1}{2} \mathrm{cc}\end{array}$ & \\
\hline $\begin{array}{l}\text { Duodenal stricture } \\
\text { anastromosis }\end{array}$ & & & $\begin{array}{l}\text { Xylocaine } 1 \% \\
5 \mathrm{cc} \text {. }\end{array}$ & \\
\hline $\begin{array}{l}\text { Umbilical hernia } \\
\text { Excision of lobe of liver }\end{array}$ & 36 hours & $7 \frac{1}{2}$ lbs. & $\begin{array}{l}\text { Xylocaine } 1 \% \\
5 \mathrm{cc} \text {. }\end{array}$ & \\
\hline $\begin{array}{l}\text { Congenital dislocation } \\
\text { of hip }\end{array}$ & 3 years & & $\begin{array}{l}\text { Xylocaine } 2 \% \\
6 \mathrm{cc}\end{array}$ & Pentothal \\
\hline 2 hip fusions T.B. & $6 \& 7$ years & & $\begin{array}{l}\text { Xylocaine } 2 \% \\
10 \mathrm{cc} .\end{array}$ & 2 Pentothal \\
\hline
\end{tabular}

thetic. Procaine as an agent was unsatisfactory, as the time limit was too short. Xylocaine has overcome that difficulty. It is true that xylocaine (5) is not hydrolized but is excreted as such by the body and therefore could be considered more toxic than procaine. However, in actual practice, there has been no clinical evidence of an increased toxicity in infants and children. For adults, the continuous or intermittent catheter technique has been used with success elsewhere. Obviously this technique would be impossible in infants owing to the size of catheter. Furthermore, there is no need for an intermittent technique with xylocaine, for 1 per cent will last at least 1\% hours and 2 per cent at least 3 hours.

There is a definite need for skill in identifying the epidural space. Some of the early workers used the method of doing a spinal tap and withdrawing the needle one or two millimetres until there was no spinal fluid and then injecting a small amount of solution. If no spinal anaesthesia developed in 5 minutes, the remainder of the solution was injected. In several cases $I$ have used this method and no 
spinal anaesthesia has developed. Another method I have used is that described by Dogliotti and others. It is based on the disappearance of resistance against the plunger of the syringe as the needle with syringe attached is advanced through the interspinous ligament and ligamentum flavum and enters the epidural space. Macintosh (6) has described the use of a small balloon attached to the epidural needle which deflates when the point enters the epidural space. I have not used this. I feel that the disappearing drop is a safe and easy method. The needle must have a short bevel and a stilette. The infant must be held firmly in a flexed position. It has been my experience that patients having dependent oedema or having large intro-abdominal tumours do not have a negative epidural pressure. In spite of the recent experimental work on diffusion (7) of epidural solutions, I do not believe that procaine or xylocaine enter the subarachnoid space in sufficient concentration to produce a clinical spinal anaesthetic. This is borne out by the fact that each abdominal patient moved its feet when stimulated before and immediately after operation.

There have been no complications attributable to the anaesthetic agent or technique with the exception of one in which the intravenous needle used for the tap was plugged with dried blood; this caused a localized subcutaneous reaction, which resolved with treatment. There have been no convulsions or other toxic manifestations from the anaesthetic agents. There has been no evidence of neurological sequelae. Blood pressures have not been taken. Pulses have remained good in quality. Respirations have been quiet and unlaboured, not of the type so often seen with open ether. Relaxation has been truly remarkable. The post-operative course has been $\mid$ very satisfactory-even with the intussusceptions and the volvulus, which were desperate cases. Only a small number of infants with pyloric stenosis have required transfusion. There are two precautions to be taken, however; one is to maintain body temperature, and the other to keep the infant in a flat or slightly Trendelenburg position for three hours post-operatively, or until abdominal tone has returned to normal, in order to prevent pooling of blood in the visceral area and lower extremities.

The attitude of surgeons and paediatricians to this form of anaesthesia has been interesting. At first one could feel a slight scepticism, but they have since become agreeably impressed with its use in infant surgery so that now there is often a request for "one of those epidural blocks."

Epidural anaesthesia is a definite addition to the techniques applicable to paediatric anaesthesia. There is a certain risk which depends to a great degree on the skill of the anaesthesiologist. No one should attempt such an anaesthetic in an infant unless he has had considerable experience in adult epidurals. Just as an increased vigilance and skill are necessary for safe use of our modern adjuncts to general anaesthesia, so are awareness of and ability to cope with the hazards which may arise in this anaesthetic.

\section{SUMMARY}

Epidural anaesthesia has been employed in 77 infants since 1949 for the operation of pyloroplasty, for other abdominal procedures such as intussusception, resection of bowel, hernial repairs, splenectomies and for operations on the hip joint. The agents were procaine 1 or 2 per cent in the earlier cases, and xylocaine 1 or 2 per cent with epinephrine $1 / 200,000$ in later cases. The technique has 
been satisfactory to anaesthetists and surgeons. The author's technique is described.

\section{RÉSUMÉ}

Ce texte décrit l'expérience de l'auteur dans l'emploi de l'anesthésie épidurale chez les nourrissons et les enfants, de 1949 jusqu'à présent. Ce n'est que tout récemment que l'auteur a trouvé une référence dans les textes à son emploi antérieur.

Au début l'agent employé fut la procaïne, $1 \%$ ou $2 \%$, remplacée plus tard par l'xylocaïne $1 \%$ ou $2 \%$ avec $1 / 200,000$ d'épinéphrine. Des canules lombaires spéciales de 2 pouces, jauge No. 22 à biseau court furent employées. La méthode d'identification de l'espace épidurale fut cẹlle de la goutte pendante qui disparaît dans le moyeu de la canule à cause de la pression négative dans l'espace épidurale. L'enfant est maintenu dans une position aśsise, par l'assistant, qui le tient coudes aux genoux, empêchant ainsi le mouvement de l'enfant. Le dosage moyen pour un enfant de 7 à 8 livres est de 5 à $6 \mathrm{cc}$ d'xylocaine $1 \%$ en dosage unique dans T10-L1 pour les opérations abdominales supérieures et dans L1-L4 pour les hernies et les procédés orthopédiques. L'anesthésie avec relâchement marqué s'ensuit en 10 minutes. Des agents anesthésiques supplémentaires furent le pentothal, le cyclopropane ou le protoxyde d'azote. Soixante-dix-sept épiduraux furent administrés avec une seule complication due à l'anesthésie et cela une réaction subcutanée causée par du sang coagulé provenant d'une canule bouchée avant l'emploi dans la technique de canules lombaires. La majorité des cas consistait en opérations sur le pylore (53) mais d'autres procédés abdominaux furent employés tels l'étranglement, l'excision de l'intestin, des réparations herniaires, la dissection de la rate et des opérations sur l'os de la hanche.

L'habileté de l'anesthésiste doit être grande pour empêcher l'injection intradurable ou le dommage aux nerfs. Il faut être habile dans l'emploi de cette technique chez l'adulte avant de l'essayer chez l'enfant. Cette façon d'amener l'anesthésie est très utile lorsqu'il y a accompagnement d'infection respiratoire, ketosis, etc., et dans les cas où les machines à administrer le gas ne sont pas adaptables à l'anesthésie de l'enfant. Les chirurgiens sont contents à cause du relâchement maximum et de la respiration paisible des patients. Cependant il faut souligner qu'on doit veiller aux hasards de ce type d'anesthésie et savoir et pouvoir remédier avec efficacité aux complications.

\section{REFERENCES}

1. Srevers, R. Peridural Anaesthesia for Cystoscopy in the Child. Arch. f. klin. Chir. 185: 359 (1936).

2. Dogliotrt, A. M. Anesthesia. Chicago: Debour (1939).

3. Southwonth, J. L. \& Hingson, R. A., ed. Pitkin's Conduction Anesthesia. Philadelphia: Lippincott (1946).

4. Leigh, M. D. \& Belton, M. K. Pediatric Anesthesia. New York: Macmillan (1948).

5. Foldes, F, F. Epidural Anesthesia: A Re-Evaluation. Paper read at International Congress of Anaesthetists, Quebec City, October, 1953.

6. Macintosh, R. R. Lumbar Puncture and Spinal Analgesia. Edinburgh: Livingstone (1951).

7. Frumin, M. J., Schwartz, H., Burns, J. J., Brodie, B. B. \& Papper, E. M. Sites of Sensory Blockade during Segmental Spinal and Segmental Peridural Anesthesia in Man. Anesthesiology 14:576 (1953). 